\title{
CASTRO ALVES EM SÃO PAULO E NA SUA FACULDADE DE DIREITO
}

\author{
Rubens Limongi França \\ Professor Aposentado da Faculdade de Direito da Universidade de São Paulo
}

Oração oficial proferida no Salão Nobre da Faculdade em 11 de agosto de 1997, às 10 h00 com a presença do Excelentíssimo Ministro da Cultura, do Magnífico Reitor da Pró-Reitoria e do Diretor da FDUSP

Em muitos autores, como Xavier Marques, Afrânio Peixoto, Pedro Camon, Pereira da Silva, Oliveira Ribeiro Neto e tantos outros, poderíamos deparar um sem-número de excertos, dos quais cada um, por si só, serviria como epígrafe do nosso assunto, tal a uniformidade dos juízes sobre o relacionamento entre Castro Alves e São Paulo.

Por especial pertinência vejamos, por exemplo, este do baianíssimo, universalíssimo Jorge Amado. "É em Castro Alves que São Paulo vai encontrar a política, o vibrar por causas mais próximas, se afastar (sic) dos devaneios que conduziam ao reino da imaginação delirante" E em São Paulo, ao calor da simpatia com que a cidade o cerca, Castro Alves escreverá o melhor da sua obra abolicionista e republicana. Se duas coisas se compreenderam no mundo, foram Castro Alves $e$ São Paulo (ABC, p. 232).

Mas é preciso sublinhar, para que a afirmação seja de algum modo ainda mais verdadeira, que essa compreensão esteve longe de ser um tipo de amor à primeira vista.

Descontente com a acolhida que, retornando mais uma vez do Recife, lhe dera a Terra Natal e, sobretudo, com a interpretação de "O Gonzaga", "pálidas sombras que um dia creei de coração, e cuja caricatura na cena da Bahia deu-me ímpetos de atirar ao fogo" (Carta a Joaquim Augusto, "Obras" II, p. 564, $1^{\text {a }}$ ed.), tinha a vidência de que o sucesso seria outro em São Paulo, onde o aguardaria "uma platéia ilustrada"... "uma platéia acadêmica" pois com todo "o lirismo, e patriotismo, a linguagem" haveriam de ser "bem recebidos por corações de vinte anos" (lbidem, p. 563).

Por outro lado pompeava na cátedra do Largo de São Francisco o exprofessor substituto do Recife, também poeta, e sobretudo o grande tribuno da Abolição e da República, de modo que, em breve, estaria podendo dizer, como disse, 
em carta a Luiz Cornélio, datada de 20 de março de 1868: "Estou na Academia, ouvindo o grande José Bonifácio" (Op. cit., II, 551).

Mas o jovem paladino, ainda não completamente maduro, senhor dos seus talentos e encantos pessoais, tinha lá, por vezes, compreensíveis intolerâncias e extravasamentos de radicalismo.

Assim, em Carta a Augusto Alvares Guimarães, de abril de 68 ("Obras" II, 557), que, sob alguns aspectos chega a ser contraditória, traça um rascunho nada lisonjeiro da Paulicéia: "... aqui não há senão frio, mas frio da Sibéria; cinismo (no sentido romântico da palavra), mas cinismo da Alemanha; casas, mas casas de Tebas; ruas, mas ruas de Cartago... (por outra) casas que parecem feitas antes do mundo tanto são pretas; ruas que parecem feitas depois do mundo tanto são desertas..."

E naturalmente faz comparações com o aconchego morno dos recantos que deixara no rincão natal: "Escrevo-te à noite. Faz frio de morte. Embalde estou embuçado no capote, e esganado no cache-nez... Homem feliz que tu és, Augusto! A estas horas suas à fresca nos lençóis de linho, enquanto eu estou gelado com as meias de lã"

E mais adiante a apóstrofe de descabida hipérbole: "São Paulo não é o Brasil.., é um trapo do polo pregado a goma arábica na falda da América..." (Ibidem).

Mas não era só isso.

Um certo provincianismo paulistano, que aliás ainda hoje conserva a nossa Piratininga, o incomodava em coisas de hábitos pessoais. Assim, a despeito do "grande número de alfaiates" existentes em São Paulo, sobretudo, como assinala Almeida Nogueira (Tradições e Reminiscências, v. 5, p. 6) em relação ao índice populacional, não lhes poupou o garboso Cecéu critica das mais severas.

Com efeito em carta a Luiz Cornélio, a eles se refere com desmedida acrimônia: "Possui esta terra de São Paulo estúpidos alfaiates. - Preciso de algum fato do Rio. Far-me-ás o obséquio de ir à casa do Sr. João Francisco Rabello, Rua do Ouvidor n. 104, e de dizer-lhe que a minha pessoa tem as mesmas proporções físicas do Cardoso de Menezes... Pode, pois, por ela, regular-se na confeç̧ão da roupa de que te falo, e que deve constar de um paletó preto, um dito de casimira, duas calças e dois coletes de casimira sendo uma clara e outra escura... Peço-te toda e toda a pressa na remessa, se for possível até o 7 de setembro" (Carta de 24 de agosto, in "Obras": II, 561). 
Entretanto, não é que de todo tivesse começado de mal com São Paulo, pois na própria Carta a Augusto, de abril de 68, iniciara por chamar Piratininga de "bela cidade das névoas e das mantilhas, no solo que casa Heidelberg com a Andaluzia..." ("Obras" II, p. 556).

Numa alegoria um pouco audaciosa, mas adequada ao Poeta, a noiva (São Paulo) era um pouco feia, mas não deixava de ter os seus encantos. E esses encantos se lhe antolharam muito depressa, como soe acontecer com a maioria das damas recatadas...

De pronto, o convívio que aqui encontrou sob a égide daquele a quem considerava "o grande José Bonifácio" o aconchego dos moços, especialmente os da Bucha que tão perto sempre dele estiveram, com seu espírito de solidariedade e a tradição liberal, a vida social para cuja participação sempre era convidado, repleto de rostos morenos, de uma caboclice refinada, tão do seu agrado, os resquícios do cinismo byroniano deixado por Álvares de Azevedo e por seu amigo e até certo ponto, nos primeiros encontros, seu mentor - Fagundes Varela; o espírito de Cultura que, dentro dos lares e dos salões, contrastava com a provincianice do aspecto externo do casario, onde foi encontrar os ecos do "Moço Paulistano" - Carlos Gomes, a quem se refere no poema "A Minha Irmã Adelaide", de maio de 1871 (um dos últimos de sua vida, "Obras" I, p. 452), isso (e haveria muito mais a dizer) foi mostrando a Castro Alves a São Paulo que, de certo modo, já esperava e não o haveria de desiludir.

Haveria muito mais, dissemos. Sim. Mas sobretudo duas coisas: a vertigem da merecida Glória; e a lealdade bandeirante, à hora do sofrimento, pois, como dissera Ovídio, amicus certus in re incerta cernitur.

Sobre a Glória, excedeu-lhe a expectativa.

Na Carta a Augusto, já de abril de 68, várias vezes citada, noticiava: "Devo dizer-te que houve aqui um brilhante sarau literário. Pianistas, cantoras, oradores, valsadores, virtuoses, etc., etc... Aí me achei e, entre amigos, se algum dia obtive um triunfo não foi noutro lugar" Diga-se por acréscimo que, segundo reporta - "Muitos lentes da Academia aí se achavam... e todos me receberam da maneira mais lisonjeira". E houve até uma esposa de cônsul inglês que fez questão de cumprimentá-lo do melhor modo que até hoje conseguem fazer: "Mim gostar muito da sua recitativa" ("Obras", II, 557-558).

Daí escrever ao ator Joaquim Augusto afiançando a natureza ilustre e culta da platéia paulistana e a antevisão do sucesso de "O Gonzaga" 
E a realidade não foi diversa. Aos 4 de novembro escrevia a Luiz Cornélio - "a representação do meu drama, que tanto movimento fez na Imprensa e que aqui, na última prova, a da cena, acaba de obter um sucesso imenso, um verdadeiro triunfo"

Mas... veio a hora do Sofrimento. Scriptum erat. Segundo os Livros da Sabedoria, há tempo para tudo - omnia tempus habet... tempo para rir - tempus ridendi... e tempo de chorar - tempus plangendi (Eclesiastes, 3, 4).

Logo após a suprema glória de "O Gonzaga" e a aprovação plena no $3^{\circ}$ Ano da Faculdade, em 7 de novembro, veio o dia $11 \ldots$ e o tiro no pé.

E a notícia a Luiz Cornélio: "Estou há 20 dias de cama de um tiro que dei em mim mesmo, por acaso. Este desastre caiu-me na pior ocasião"

Nem avaliava quanto.

Começava o seu Calvário.

E uma legião de Cirineus de São Paulo e da Academia, entre eles Brasílio Machado, Rubino de Oliveira e o Padre Chico, tudo fizeram para ajudá-lo na penosa subida da redenção.

Daí a sua carta "Aos Amigos de São Paulo". com esse nome divulgada por Xavier Marques e Afrânio Peixoto ("Vida de Castro Alves". p. 243; "Obra", II, p. $566,1^{\mathrm{a}}$ ed.).

Na verdade, trata-se de missiva destinada, como está no "Correio Paulistano". de 30 de maio de 1869, "a alguns amigos desta capital" sendo que, da mesma, esclareceu o jornal que estava a divulgar "alguns trechos"

Esta nossa pesquisa foi realizada in loco, na Biblioteca Central da Faculdade de Direito e, a bem da verdade histórica, não se trata, de uma carta aberta a amigos em geral, como poderia parecer, idéia que chegaria mesmo a desmerecer a imagem do Poeta, pois aí fala de coisas e sentimentos extremamente intimos.

Sua divulgação, entretanto, pelo periódico, a pedido dos destinatários, foi mais uma demonstração da pungente tristeza e solidariedade que o sinistro causou em toda a alma paulistana.

Por outro lado, graças a essa publicação, a História ficou ciente de como e até que ponto São Paulo esteve junto de Castro Alves em momentos tãodifíceis, bem assim de que modo o Poeta lhe ficou enternecidamente grato.

Vejamos alguns dos seus excertos mais expressivos, a partir de quando descreve o fato de ter podido levantar-se para viajar à Corte, acompanhado do "incansável Dr. Rubino": "Eis-me na Corte há quatro dias, eu, pobre inválido, que 
não podia chegar até a sala!... Que força, que mola estranha deu vida ao cadáver? Foi Deus. $O$ Deus de Lázaro sustentou-me nesse instante em que a amizade acompanhou-me"

A seguir, a referência ao adeus a Piratininga, constitui passagem de especial significado: "E custou-me bem aquele último abraço a bordo, à tarde, quando o vento do mar começava a trazer não sei que tristeza do frio das vagas, quando uma nova peregrinação de penitência começava"

"Custou muito. Custou como agora, que eu estou lembrando-me do passado, do tempo em que eu sofri, mas no qual a cada dor, que me lacerava, tinha uma mão de amigo para apertar. Seis meses vividos na comunhão mais santa na comunhão do pensamento, seis meses em que a minha cabeça desfalecida encontrava sempre um bom coração - onde repousar..."

Particularmente, as madrugadas de março e abril, em que o Poeta esteve próximo à agonia, foram aí lembradas com grande emoção: "Lembras-te das noites de 30 de março e primeiro de abril? Foi a afeição quem me salvou"

"Mas para que desfiar este rosado santo de saudades e gratidão? Falemos de viagem"

Por fim, articula o Poeta as pungentes palavras da despedida final:

"Meus amigos, agora adeus! Se o braço tivesse força, longa seria esta carta; mas, se o meu coração não cansa de os estimar, a minha mão desfalecida me diz que pare de escrever...

A missiva, de 25 de maio de 1869 , mais tarde, em fevereiro de 1870 é de certo modo confirmada no Prólogo das "Espumas Flutuantes" que em suma é uma preciosa dedicatória aos "amigos das terras do sul", onde penetrara "como Rafael subindo as escadas do Vaticano"

É a esses amigos, à altura em que trazia "por única ambição - a esperança de repouso" nos braços da Mãe-Terra, que dedica o mais brilhante dos seus livros para que os seus versos pudessem "efêmeros filhos" de sua alma - "levar uma lembrança de mim às vossas plagas!...

Como selo indelével de sua aliança com Piratininga, ostenta, no frontispício, o galardão: "Estudante do $4^{\circ}$ Ano da Faculdade de Direito de São Paulo"!

São Paulo, 18 de março de 1997. 




O poeta Castro Alves em seu primeiro ano no Curso de Direito desta Faculdade. 